Mongolian Geoscientist

Original article

\title{
Preliminary results of biostratigraphic studies of Lower Cretaceous sediments in the Ergel-Khaliv area, SE Mongolia
}

\author{
Luvsantseden Uranbileg $^{1 *}$, Sukhbat Purevsuren ${ }^{1}$, Byambaa Purevsuren ${ }^{1}$, Batkhuyag Enkhbaatar ${ }^{1}$, \\ Batsaikhan Buyantegsh ${ }^{1}$, Bayasgaa Ganzorig ${ }^{1}$, Enkhtaivan Zorig ${ }^{1}$, Jalbaa Undarya ${ }^{2}$
}

${ }^{1}$ Division of Paleobotany and Paleozoology, Institute of Paleontology, Mongolian Academy of Sciences, Ulaanbaatar, 15160, Mongolia ${ }^{2}$ Department of Geology and Hydrogeology, School of Geology and Mining Engineering, Mongolian University of Science and Technology, Ulaanbaatar 14191, Mongolia

*Corresponding author.E-mail: uranbileg7010@gmail.com

\section{ARTICLE INFO}

Article history:

Received 02 March, 2020

Accepted 24 May, 2020

\begin{abstract}
The research area is located in the territory of Khatanbulag soum, Dornogovi province, in the Great Govi Province (coordinates: 108 $25^{\prime} 39.04^{\prime \prime} \mathrm{E}$ and $43^{\circ}$ $\left.10^{\prime} 11.43 " \mathrm{~N}\right)$. Here, the authors studied the composition of sediments that had previously been classified as Lower Cretaceous Khukhteeg Formation, forming Mt. Ergel-Khaliv during earlier mapping work. The authors revealed fossils of faunas and floras, processing some data of biostratigraphic survey works taken on fossilbearing sediments of the area. The fieldwork was conducted in April 2019 by researchers from the Institute of Paleontology, Mongolian Academy of Sciences. The area is very rich in fossils of mollusca, therefore, the local communities named it Dun-Ovoo (Conch hill). During the previous studies, the sediments outcropping around the Ergel-Khaliv were classified as Khukhteeg Formation $\left(\mathrm{K}_{1} \mathrm{ht}\right.$, AptianAlbian) based on lithological characteristics and comparing them to the type section of the Khukhteeg Formation sediments. Our research revealed biostratigraphic basements and recorded previous data of collected fossils two types of mollusca; we have studied plant fossils, turtles, ostracods, fish and dinosaur bones had been revealed at first in that area. The results of the research work, the fossils that found in the mountain, were amended by more and new types and families of fauna and flora and their constituents. These new findings were helpful in the precise determination of the age of the sediments and provided some information on the paleoenvironmental conditions of the sedimentation period.
\end{abstract}

Keywords: Biostratigraphy, Formation, sedimentation, fossils

\section{INTRODUCTION}

Location and geomorphology of the site: The Ergel-Khaliv fossil-bearing area is located in 80 $\mathrm{km}$ to the North of Mongolia's southern border, in more than $60 \mathrm{~km}$ south-west of Khatanbulag, Dornogovi province, and $100 \mathrm{~km}$ to the East of Khanbogd, Umnugovi province (Fig. 1). In general, the surface of the site is elevated from up to 1,000 meters above sea level, with a relatively flat landscape characterized by minor hills and plains. The Mt. Ergel-Khaliv consists mainly of low hills with flat tops, which are composed of the Lower Cretaceous sediments. The minor hills and ridges are characterized by significant outcrops which are separated by a number of narrow and dry streams. Fig. 2 shows

(C) The Author(s). 2020 Open access This article is distributed under the terms of the Creative Commons Attribution 4.0 International License (https://creativecommons.org/licenses/by/4.0/), which permits unrestricted use, distribution, and reproduction in any medium, provided you give appropriate credit to the original author(s) and source, provide a link to the Creative Commons license, and indicate if changes were made. 


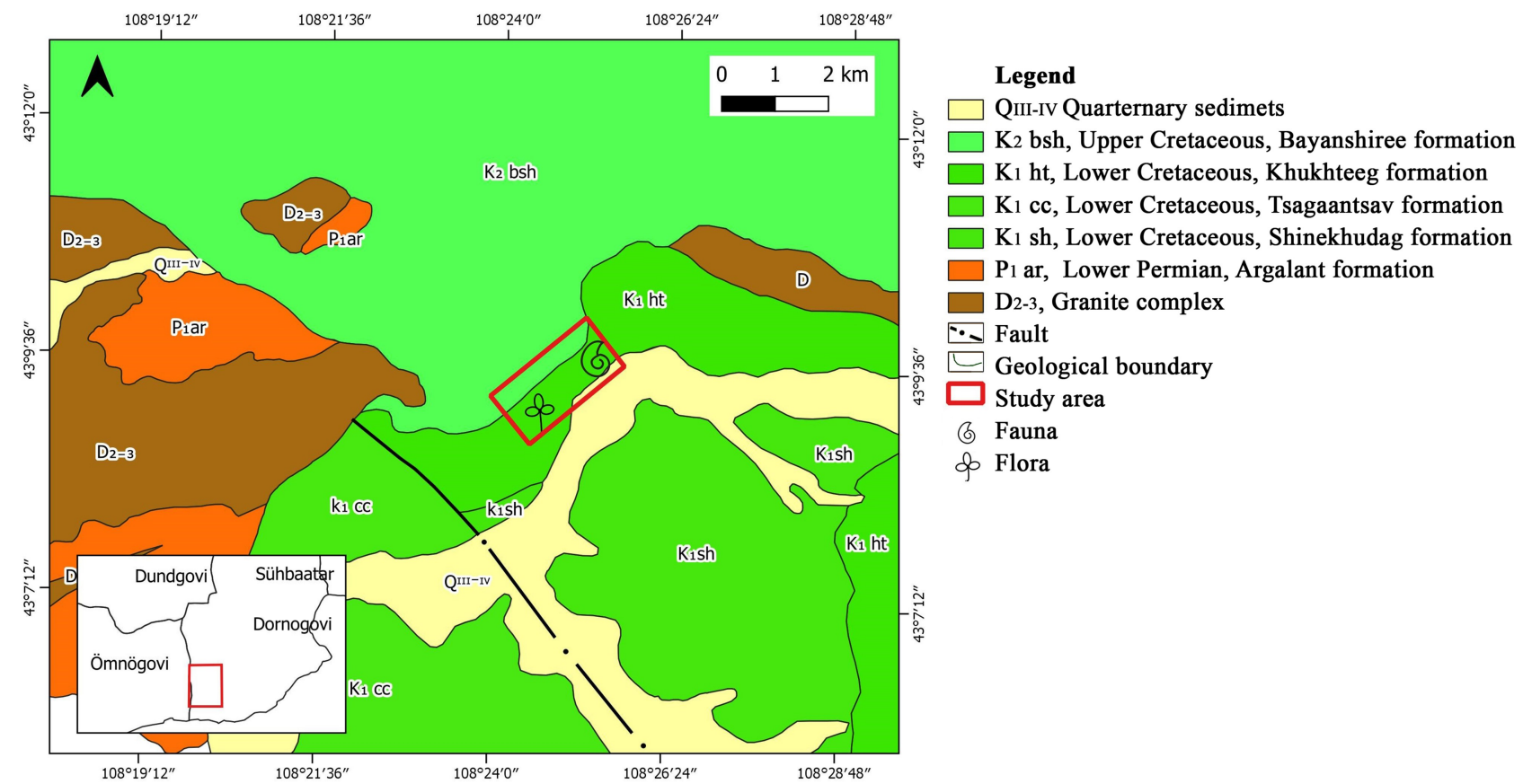

Fig. 1. Location of the Ergel-Khaliv area on geological map

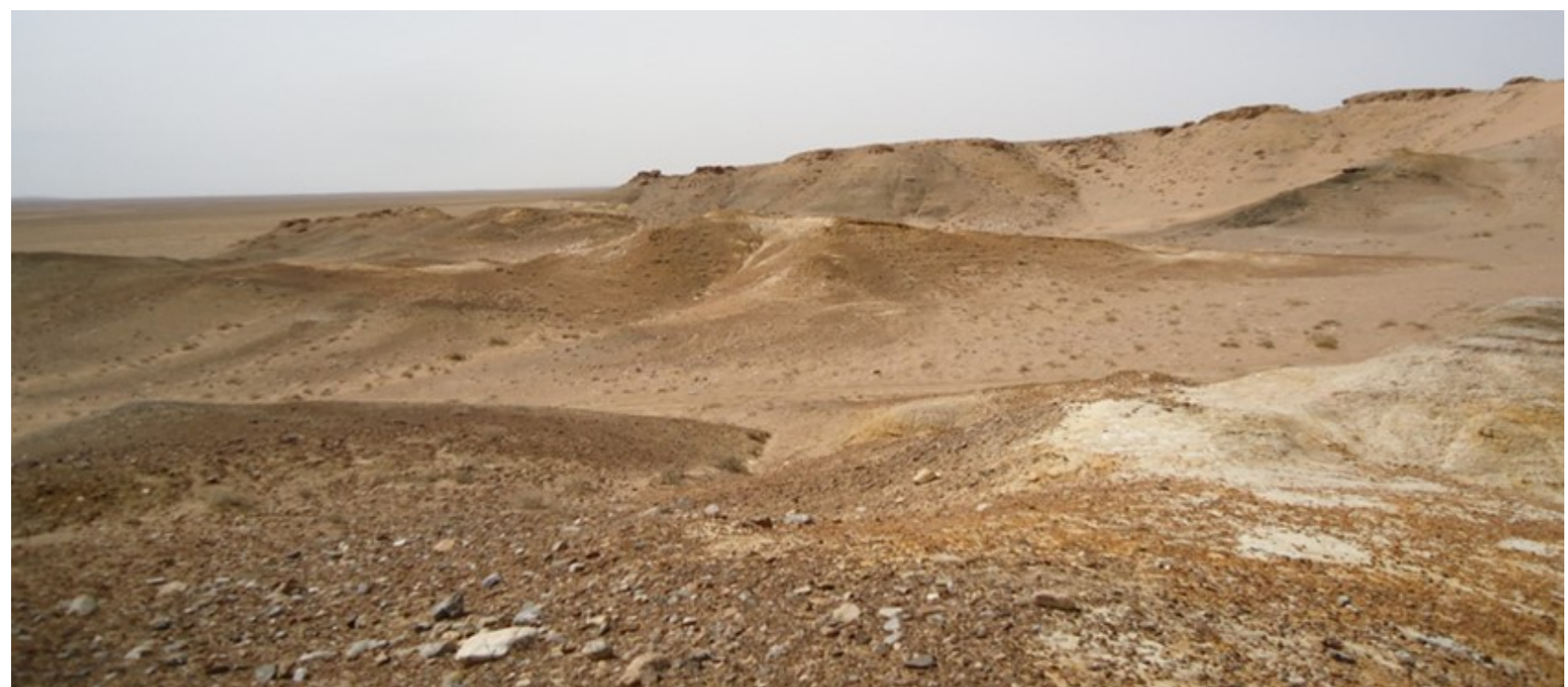

Fig. 2. Typical view of landscape and sedimentary outcrops in the Ergel-Khaliv area

a panoramic view of the fossil-bearing site and outcrops of the surface.

\section{PREVIOUS STUDIES}

Khukhteeg Formation ( $\left.\mathrm{K}_{1} \mathrm{ht}\right)$. Initially, the sediments of Khukhteeg Formation are equivalent to Upper part of Zuunbayan Formation (Turishchev, 1955) in the eastern Mongolia. The Khukhteeg Formation sediments cover unconformably the Shinekhudag
Formation and are covered by the Upper Cretaceous sediments of Sainshand Formation unconformably, too, at the Khukhteeg hill in territory of Undurshil soum, Dundgovi province. The Khukhteeg sediments are composed of greenish gray mudstone, siltstone, sandstone, limestone and conglomerate beds containing fossils of mollusca. The measured thickness of the sediments ranges between 250 and $470 \mathrm{~m}$. These sediments were identified and 
classified into the Lower Cretaceous (AptianAlbian), and named after the hill (Khukhteeg hill) by Martinson and Shuvalov (1973). Further, the researchers determined the basic section of the formation sediments, on the Khukhteeg hill site. Later the sediments were studied by Goldenberg et al. (1978) in the area of Tsogt-Ovoo soum Umnugovi province; and in some areas of southern soums of Dornogovi province, as adequate sediments (Goldenberg et al., 1978; Burenkhuu et al., 1995; Bumburuu et al., 1999; Bayartsengel et al., 2015) of the Khukhteeg Formation, which were described as gray and yellowish-gray in color, and forming partially weathered light yellow surface. In these areas, the researchers (Goldenberg et al., 1978) have found common features that the sediments have peaty or sooty signs and grayish color pattern in most part of their distribution. Usually the sediments of the Khukhteeg Formation are overlain by the Upper Cretaceous terrigenic sediments of the Bayanshiree Formation $\left(\mathrm{K}_{2} \mathrm{bs}\right)$ with angular unconformably.

The previous researchers (Rozhdestvenskiy, 1955; Martinson, 1961; Marinov and Khasin, 1973; Martinson and Shuvalov, 1973; Makhbadar, 2012) compared Khukhteeg Formation sediments, their lithological and first paleontological studies with the Lower Cretaceous Aptian-Albian stages which spread around the Mt. Ergel-Khaliv. Before this research work the Ergel-Khaliv area for biostratigraphic research had not been done in that time.

\section{GEOLOGICAL SETTINGS AND STRATIGRAPHY OF THE ERGEL- KHALIV AREA}

We conducted fieldworks within the distribution area of the Lower Cretaceous sediments, around of the Mt. Ergel-Khaliv. The key section is located in the southern part of the Mt. ErgelKhaliv. However, there has not been established continuous cross section on the site (due to discontinuous outcrops), but the layers are clearly visible in the ascending order and can be detected along with some parallel profiles in cross direction to the outcrop strike.

Tentatively we classify this is lower Cretaceous. However, it is not clear that the correlation with the Bayanshiree Formation which covers this sediment. In the future, it will have to be clarified and investigated purposely.

The layers forming the outcropping the Lower Cretaceous sediments are generally observed as a monoclinic setting, which is common in the Mesozoic sediments, and the layers are dipping to $\mathrm{NW}$ and $\mathrm{N}$ at $5-15^{\circ}$ with an average at $10^{\circ}$. A fairly complete geological section of the sediments was documented in the central part of the monoclinic structure (Fig. 2), and the thickness of the sediment gradually decreases along strike, but lacking of complete sections on the both margins.

According to the description, the sediment is generally composed of multi-colored sandstone, siltstone, mudstone, conglomerate and green and yellow clay, coaly mudstone, and brown coal seams. The complete section is shown in Fig. 3, and the visible thickness of the layers is presented in the figures. The sediments are divided into the following three packages. Lower - clayey siltstone package (Fig. 4); Mid - coalbearing package (Fig. 5); and Upper - sandstoneclayey package (Fig. 6). The descriptions of the packages are presented below.

Lower: Clayey-siltstone package (Fig. 4) is quite weathered and its rocks are fragile (Fig. 4) having fragmentary partings forming minor monocline ridges, and they are usually composed of multi-colored clay, siltstone, and rarely thin layers of sandstone, which separated by three thin (20 to $35 \mathrm{~cm}$ thick), plate-shaped siltstone layers. In the lower part of the sediment package, there were observed Gingkoaleans. Measured thickness is $151.9 \mathrm{~m}$.

Mid: Coal-bearing package (Fig. 5) is started of light yellow, weathered yellowish-gray and yellowish- green clay layers. Usually, the sediment package is composed of gray, bluish gray mud, coaly mudstone and siltstone, containing 4 coal seams (layers), of which thickness ranges from $2 \mathrm{~m}$ up to $18 \mathrm{~m}$. Further, in the ascending order of the section, there are observed fine layers of light gray, dark gray, brownish-yellow, weathered yellow clay, and rarely bluish-gray shale. Also, there are observed number of thin layers of massive, well cemented 


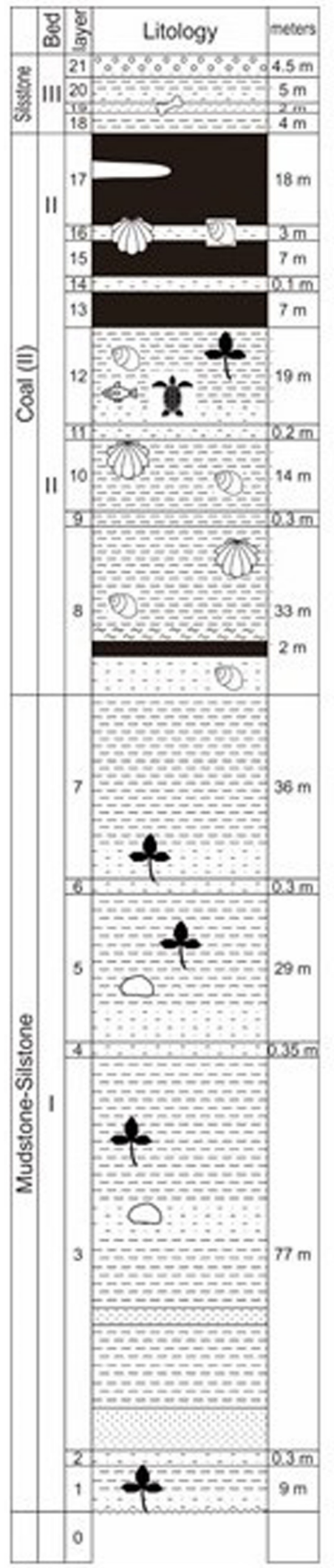

\section{Sediment Packagec I}

1.Light grey, orange clay and siltstone layers, containing leafy plant fossits and petrificd wood 2. Orange, greenish yellow colored, wrakly cementod plate-like silt-

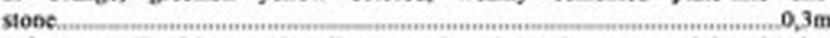
3. Orange, yellowiles grey elay siltstone and sandstone layers, containing siderite,

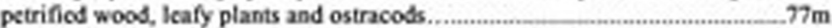
4.Siltstone layer, similar to the above second layer. ...........................35m 5. Grey, yellowiss grey elay layers, cootaining fossils of allochlobess wood, leafy plants and cotracods. $29 \mathrm{~m}$

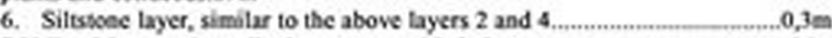
7. Yellowish grey clay, allochioeous wood is in botiom part........................36m

\section{Sediment Package-II}

8. Clay layer contuining silt-shale and two-meter bick ceal-seam at is bottom, and containing rich findings of gastropods and bivalvis .

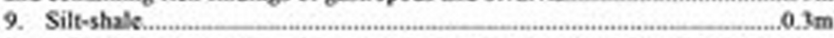
10. Yellowish groen, yellowish grey siltstone layet, coetaining siderite, gastro-

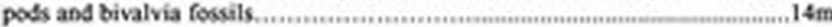

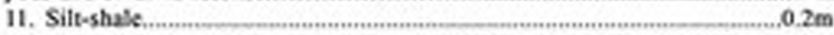
12. Yellow clay, grey colored massive and well cemeosed siltstonc and mudstone layer and earictod with irce oxide containing rich fossits of gastropods, conches. plants , and rafe fossils of fisd and turter....................................... $19 \mathrm{~m}$ 13. Coal seam..

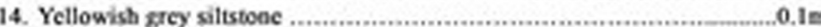

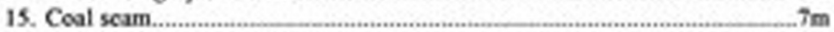

16. Yellow, bluish grey siltstone, containing of gastropods and bivalvia ....... $3 \mathrm{~m}$ 17. Coal seam containitg yellowises grey thin layers of siltsteec, diacosar bone fossils.

$18 \mathrm{~m}$

\section{Sediment Packase-III.}

18. Grey silts-3hale, yellowish grey sandstone and elay layet.................. Am 19. Sandstoec Lyct................

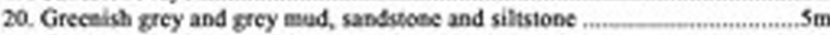

21. Coeglomerate and sandstone layer. $.4 .5 \mathrm{~m}$

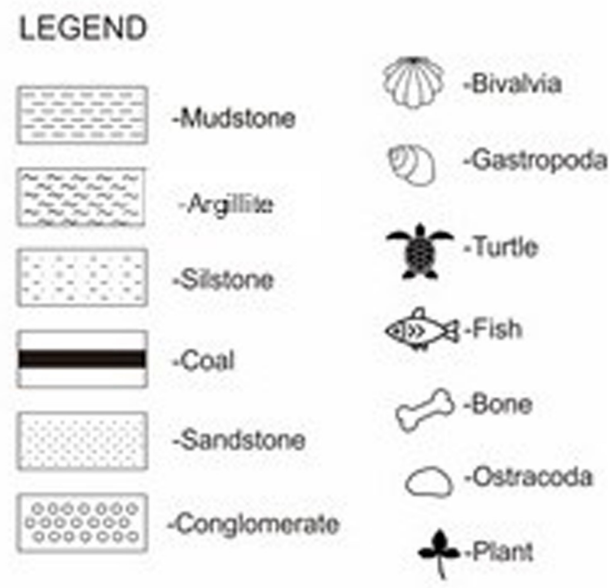

Fig. 3. Section of Lower Cretaceous sediments in the Ergel-Khaliv area 


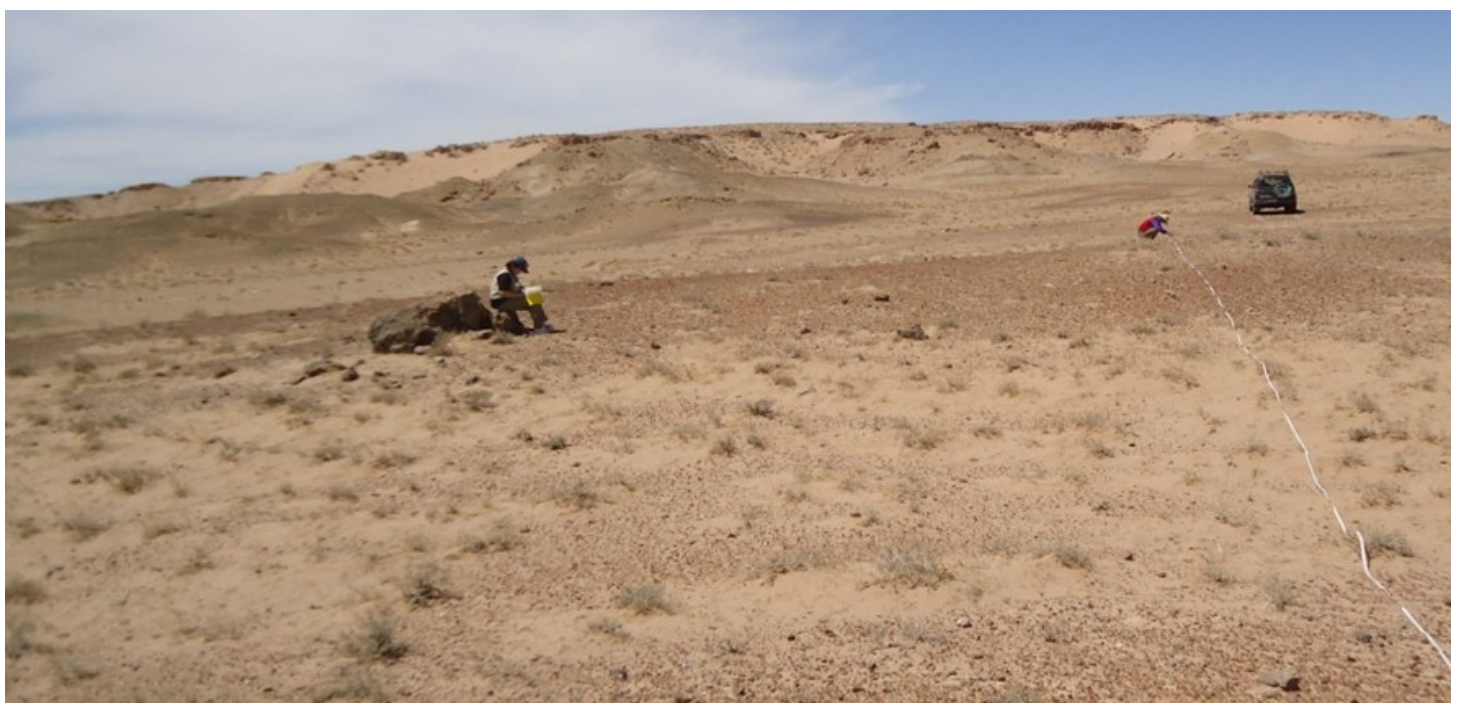

Fig. 4. View on sediments outcrop of the Lower: Clay-siltstone package

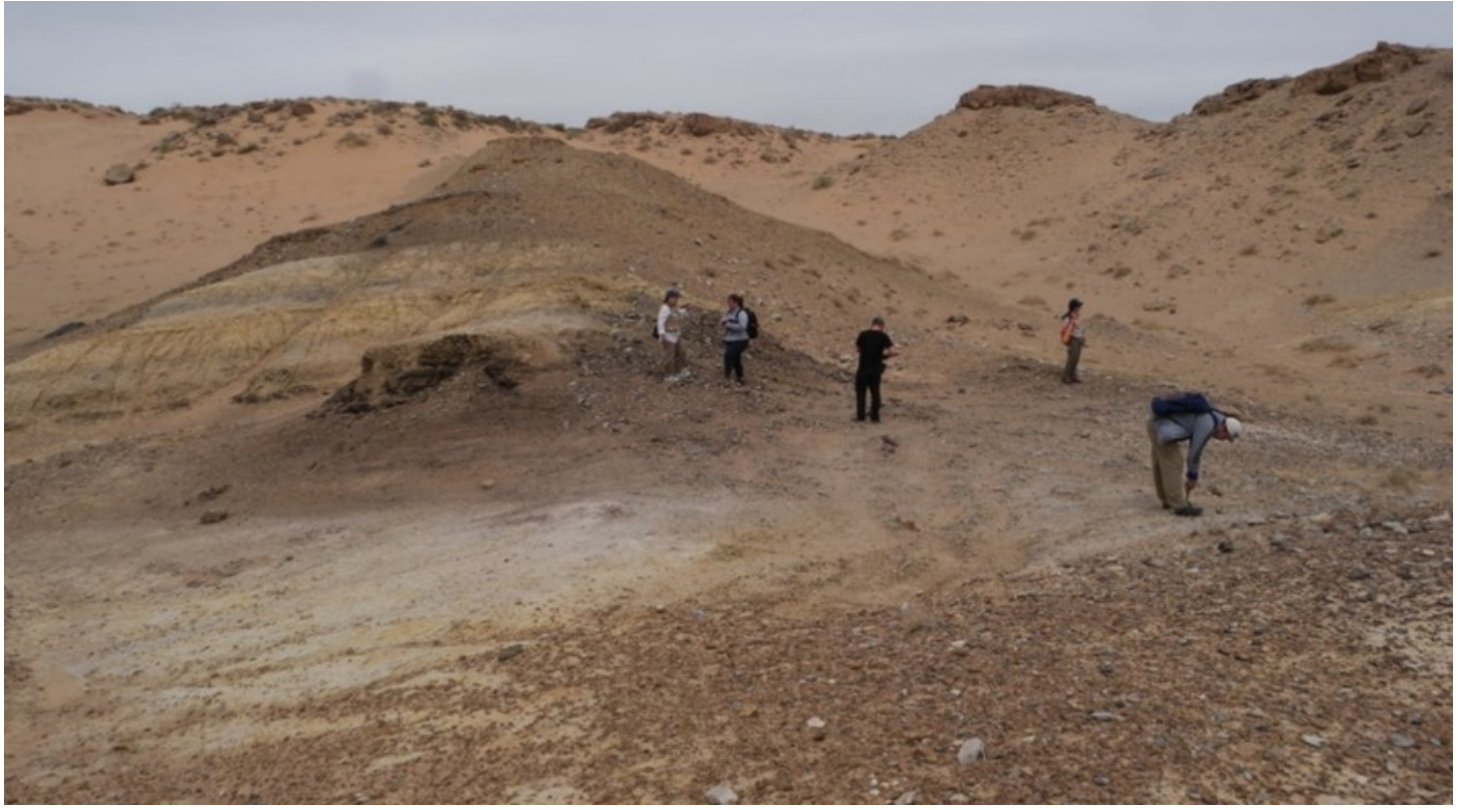

Fig. 5. Outcrop of Mid Coal-bearing package

and homogenous bluish gray siltstone, and containing very thin abundant layers of gypsum (thickness $\sim 1 \mathrm{~cm}$ ) in lower and middle parts of the sediment package. And the intermediate rock partings that located between Coal seam 1 (lower) and Coal seam 2 (second from bottom) contain siderite.

There were found and described fossils of twoshell mollusca (Bivalvia) and spiral shaped conchs (Gastropoda) and rarely backbones of fish and head and major prints of coeps of fish, and fragments of turtle and fossils of ostracods. Furthermore, we found prints of continental leafy plants and remainders of dinosaurs from upper part of the sediment package. The Fig. 5 shows the outcrop of the mid coal-seam package. Measured thickness is $101.6 \mathrm{~m}$.

Upper: Sandy-Clay package (Fig. 6) starts mainly with yellowish, greenish gray, gray shale siltstone and continues in ascending order with pre-dominated polymictic sandstone, and in quite top part of the package, violet colored thin and siltstone layer. The sediments have a monoclinic structure. There were revealed allochthonous bone fragments of probable 


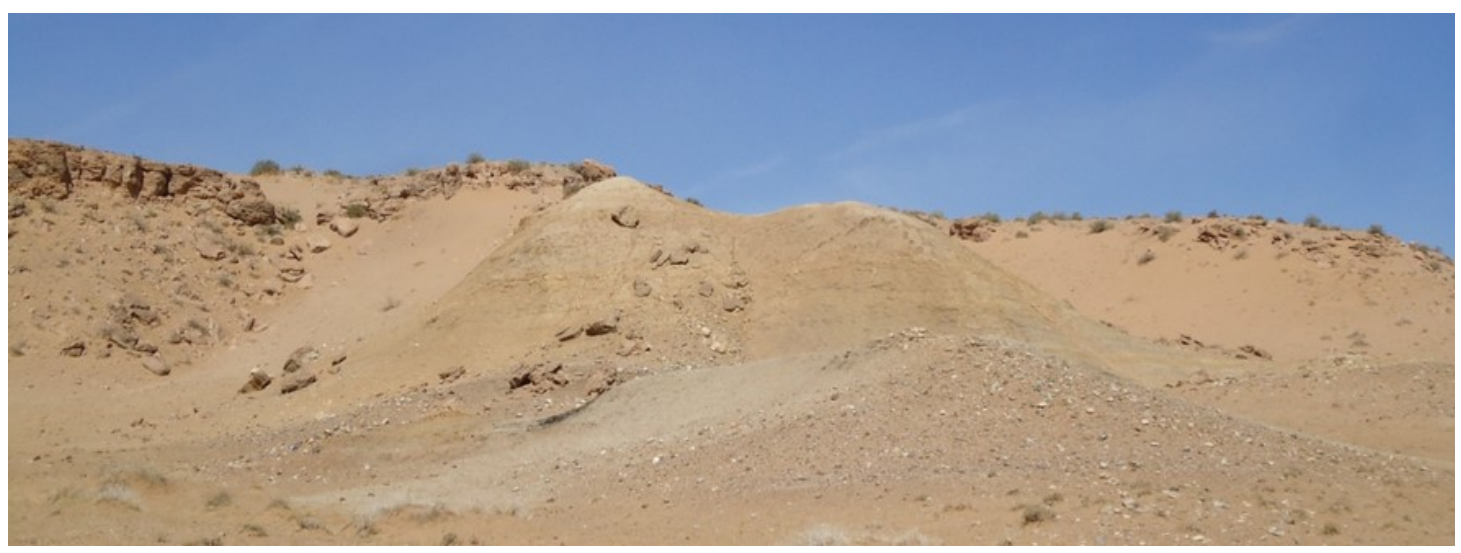

Fig. 6. Upper Sandstone-Clay package of the section

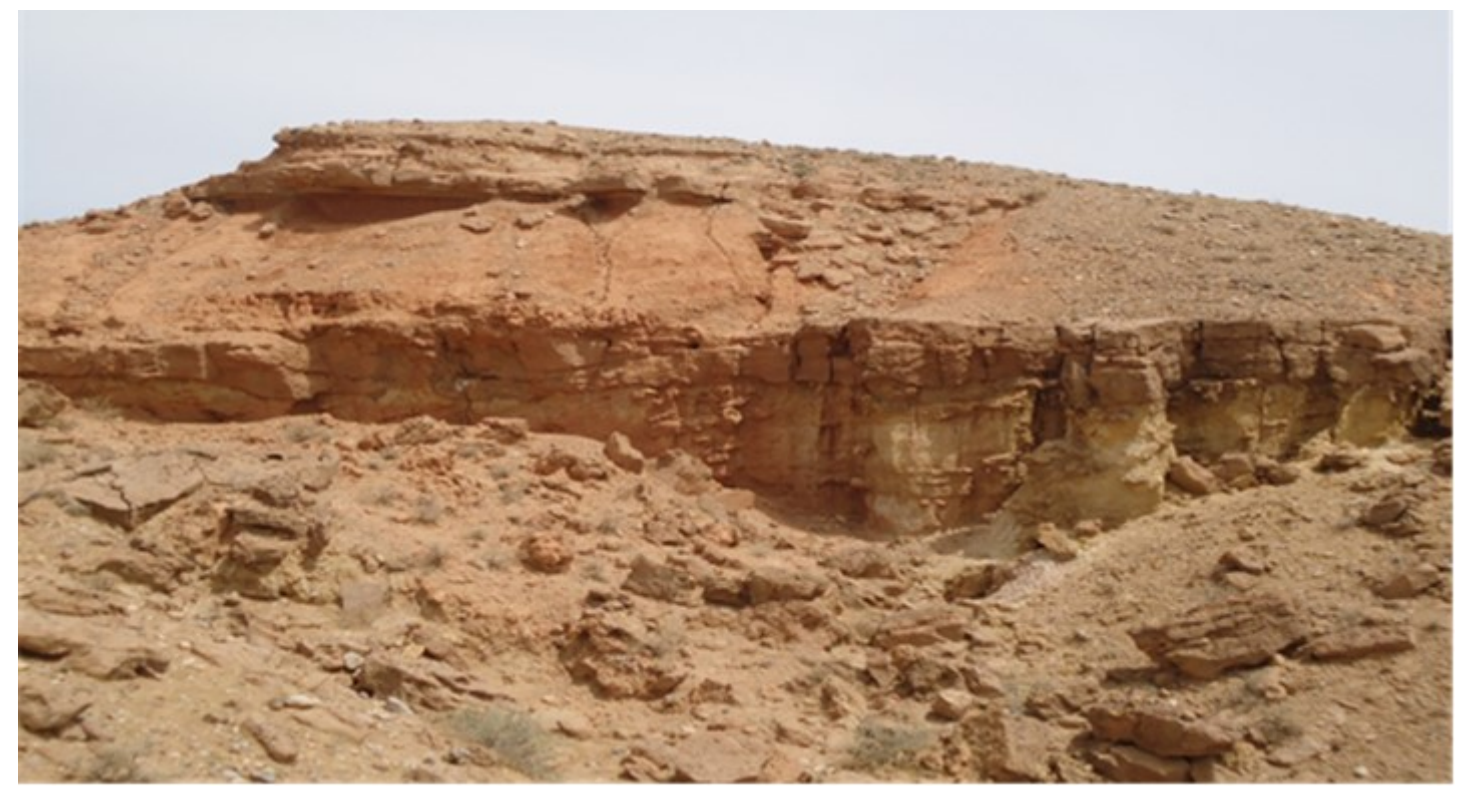

Fig. 7. View on sediment boundary that is described as existing between sediments of the Lower and Upper Cretaceous

carnivore reptilians from the bottom part of this sediment. Measured thickness is $15.5 \mathrm{~m}$.

The upper part of the section is confined to the gravelite, medium grained and surrounded conglomerate, of which thickness is up to $6 \mathrm{~m}$, and the upper part is covered by Quaternary loose sediments, forming flat surface. The thickness of the sediments decreases to westward or to direction of the western end of the hill and paleontological findings be depleted, simultaneously the coal outcrops being reduced. However, in the eastern and northeastern limbs of the hill, the coal seams were relatively greater and content of gastropod and conch fossils were more abandoned. According to results of our measurements, the total thickness of the Lower Cretaceous sediments is c. $269 \mathrm{~m}$. The thickness of the red sediments of the overlying Bayanshiree Formation (?) is 10 to $15 \mathrm{~m}$. Fig. 7 depicts the contact line between sediments of the Lower and Upper Cretaceous.

\section{Paleontological findings and age determination for the sediments in the Ergel- Khaliv area \\ A/. Plants (Appendix 1. Figs. 1-10 in Plate I). It} was assumed that the findings of the mega flora revealed in the section were largely determined by the exposed species: gingkoaleans and conifers at the peak of their development. And also, there were occurred few remainders of 
bamboo and Cycadaleans, and many more seeds. In summary, there were observed from the lower part of the section Lower Cretaceous Barremian-Aptian plants like as Sphenobaiera cf. longifolia (Pomel) Florin, Sphenobaiera sp., Pityophyllum sp. and from upper part of the section plants of species such as Acrostichopteris cf. vachrameevii E. Lebedev, Brachyphyllum sp., Nillsonia sp., Podozamites cf. eichwaldii (?) Heer, Podozamites sp., Swedenborgia sp., Ixostrobus sp. (Durante et al., 2009; Vahrameev, 1990; Krassilov, 1982). It should be noted that the species Acrostichopteris vachrameevii (Lebedev, 1974), which refers to the Lower Albanian period, was not very abundant in Mongolia. The lower part (Fig. 3) of the section composed of siltstone-clayey layers contain petrified tree trunks up to $1.75 \mathrm{~m}$ in size and allochthonous tree fragments of different sizes (Fig. 8).

B/. Mollusca-conchs are (Appendix 2. Figs. 19 in Plate II) well-preserved and in Mid coalbearing package, which have the richest fossils (Fig. 9), as mentioned above, in siltstone and mudstone layers, belonging to the genus and species of gastropods mainly Viviparus robustus Martinson, Campeloma yihsiensis Grabau, $C$. mongolica Martinson, Lioplax sp. and twoshelled gastropods like as an Unio pygmaeiformis Martinson (Martinson, 1961; Barsbold, 1972; Martinson and Shuvalov, 1973).

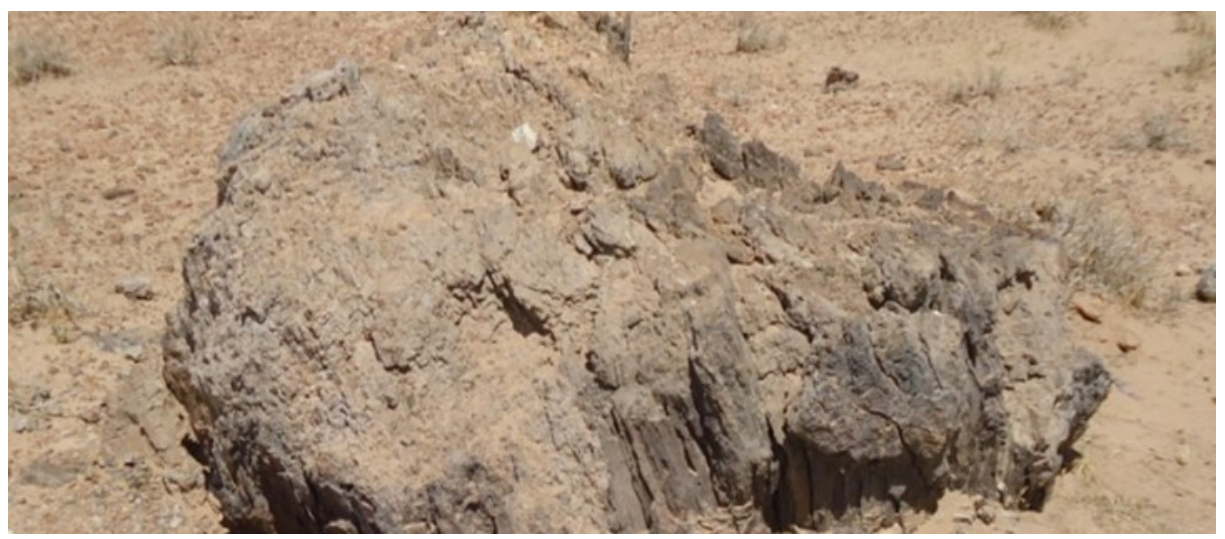

Fig. 8. View of petrified wood with a diameter of $1.75 \mathrm{~m}$ from the bottom of the lower sediment package (Scale for wood: 1:0.25)

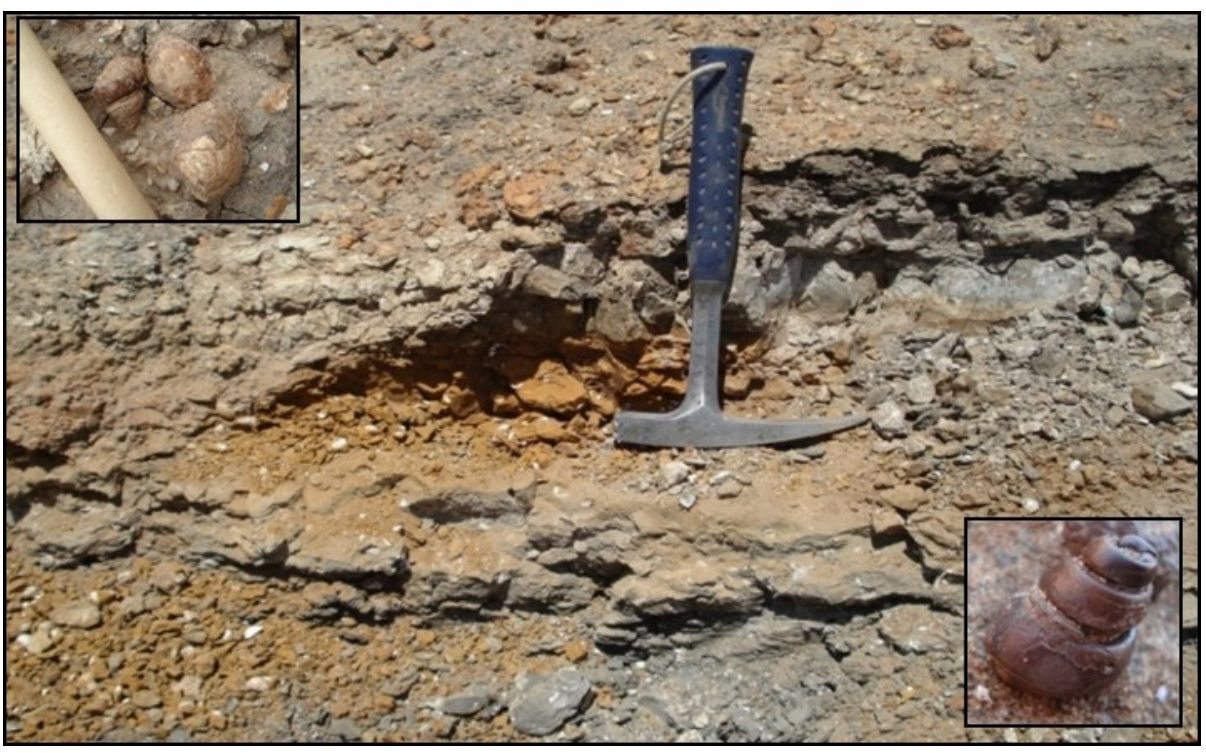

Fig. 9. View of mollusca-bearing siltstone and mudstone beds (hammer for scale) outcrops located in the upper part of coal-bearing sediment package (scale for molluscs 1:2) 
The identified molluscs (gastropod and bivalves) groups were mostly widespread in the mid and late time periods of Lower Cretaceous.

C/. Fishes are (Appendix 2. Figs. 10-12 in Plate II) found from continental sediments that had been accumulated during the Lower Cretaceous period on the territory of Mongolia. The period was sometimes referred to as the 'Lacustrine basin phase' (Berkey and Morris, 1927). In this regard, ancient species of the Lycoptera genus, which are widespread in the Early the Cretaceous sediments are found in most of East Asia, such as Mongolia, China, and
Trans-Baikal (Svichenskaya, 1954; Sychevskaya, 2004). There are found a few fossils of spine bones of the above mentioned Peipiaosteus-type fish from upper-mid layers of lower package belonging to the Ergel-Khaliv section. Also, there were revealed well preserved few spinal chords of Lycoptera-type fish in core of drill hole No. ZK-0001, from depth at the same level with the above mentioned stratum (Fig. 10). And this type of Lycoptera could not be determined at the species level due to their storage. Basically, these kinds of fishes were widely distributed in the Early Cretaceous lacustrine basins.

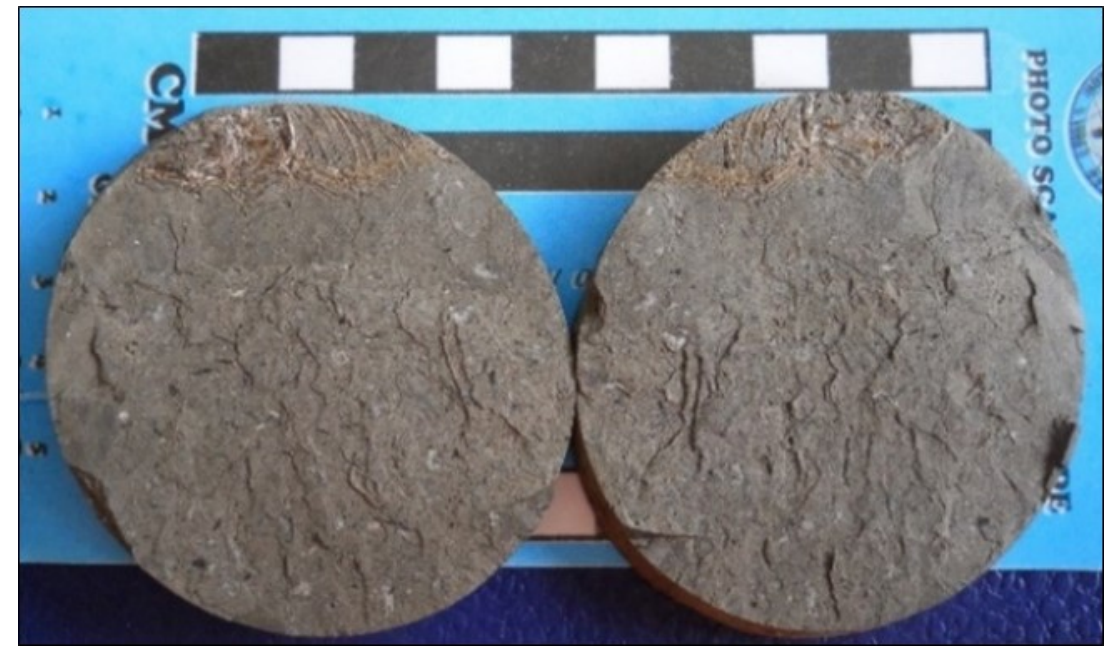

Fig. 10. View of drill core showing dark gray fish chord-bearing mudstone from the mid of sediment package on the northwestern limb of the Ergel-Khaliv section. Scale: 1:1

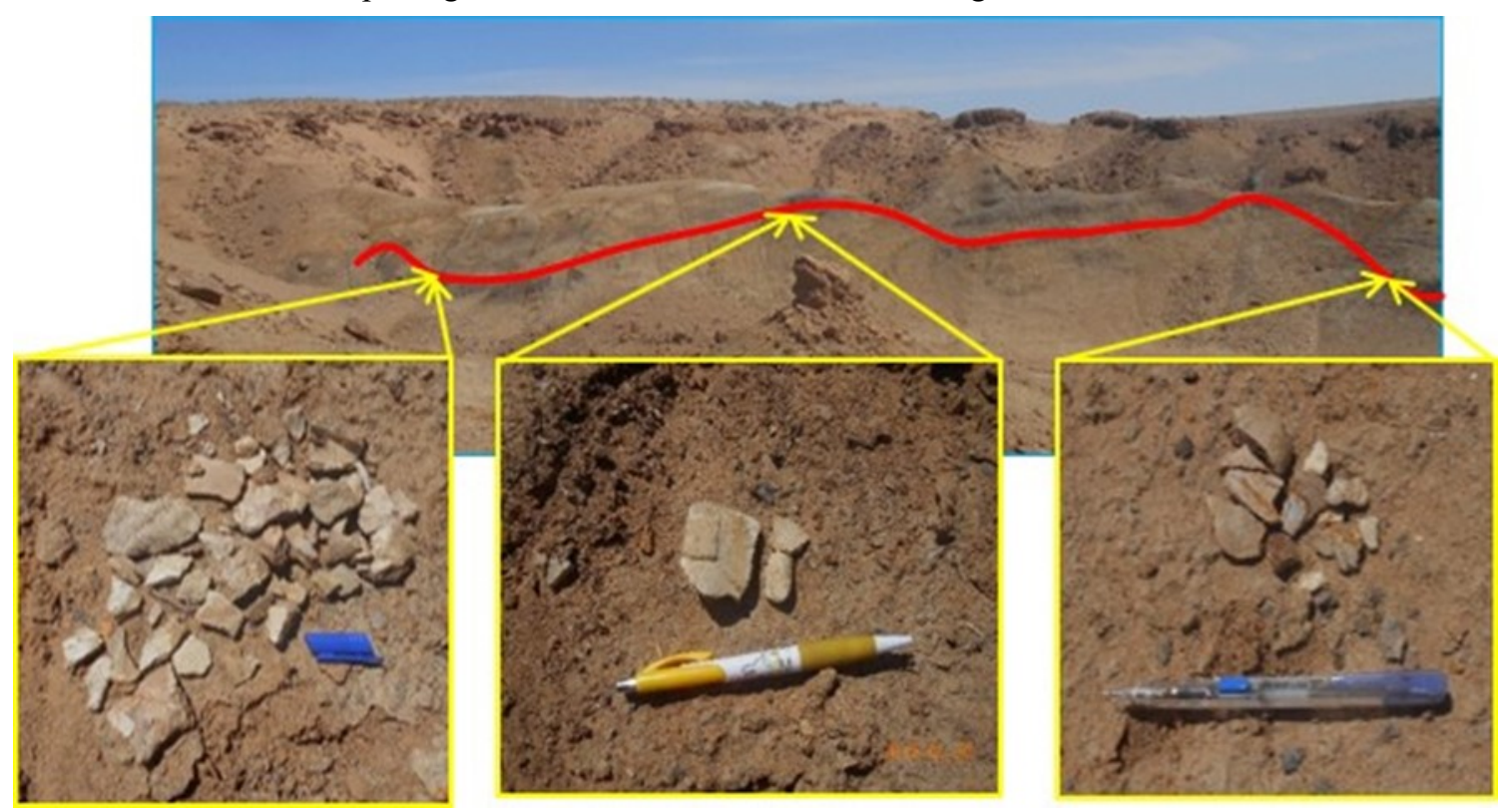

Fig. 11. Location of turtle fossils, Northwestern part of the Ergel-Khaliv section 
D/. Turtles (Appendix 2. Fig. 13 in Plate II) are preserved in sediments of Neogene to Jurassic age in Mongolia. During previous research turtles were discovered and described as two small and medium sized genus and two species. The Hangaiemys leptis Sukhanov emend Narmandakh, species found in our study were relatively widespread during the Early Cretaceous period (Sukhanov and Narmandakh. 2006). The following figure shows the middle part of the section, where the turtle fragments were discovered (Fig. 11).

E/. Dinosaurs are (Appendix 2. Figs. 14-17 in Plate II) as a result of the study, we represented that some findings that can be belonged to the species that had existed for the Early Cretaceous or Mid package of the Lower Cretaceous and those findings depends on the upper layers of coal-bearing mid package sediments of the Lower Cretaceous. The location, where few

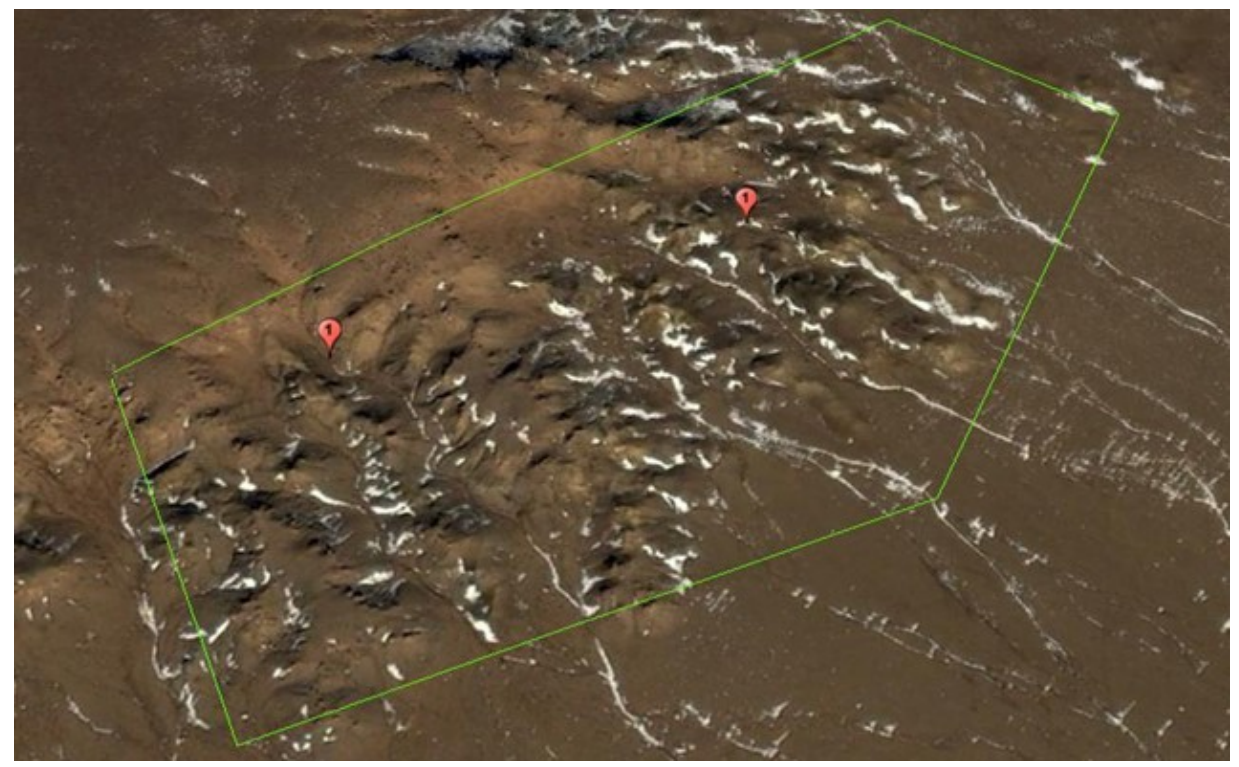

Fig. 12. Location, where some fossilized fragments of dinosaur are revealed

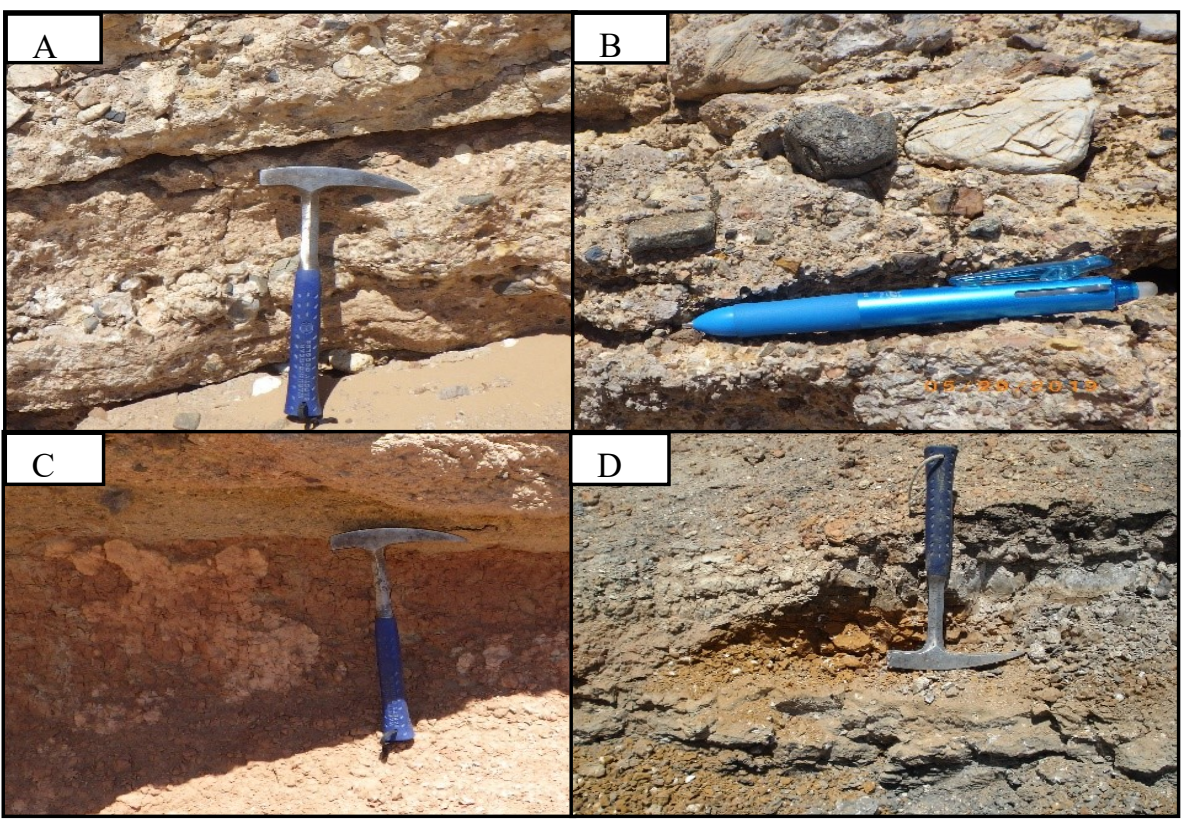

Fig. 13. A and B -shows pebble size conglomerate; C - view of red colored clay beds; D -shows gray, dark gray and yellowish gray massive clay bed 


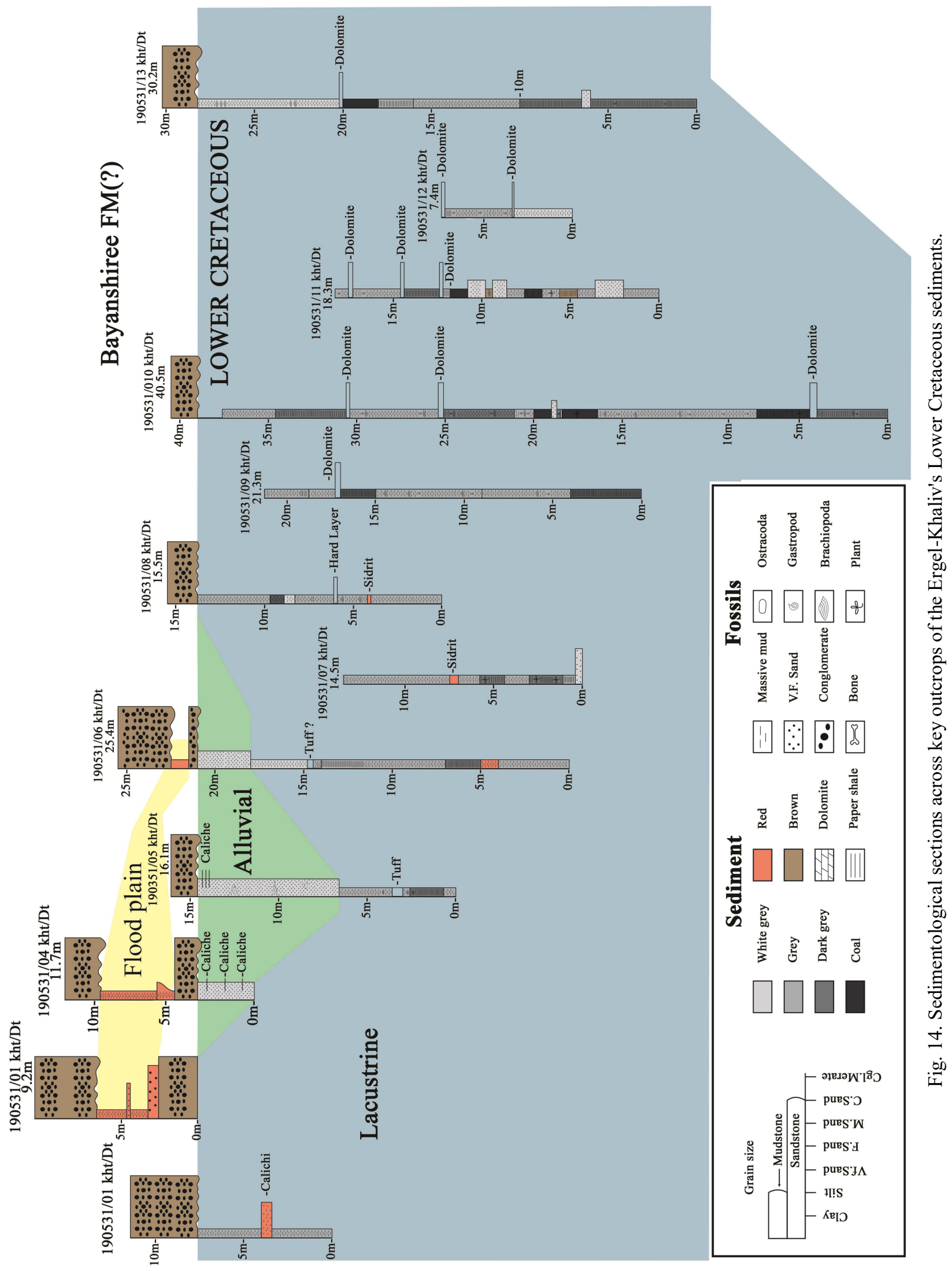


fossil fragments are revealed from the sediments that could be belonged to dinosaur species of Psittacosaurus (Osborn, 1924) and other carnivores are shown on the map, see Fig. 12. Unfortunately the fossils could not be determined at the genus level due to poor preservation.

F/. Ostracods are (Appendix 2. Figs 18-20 in Plate II) abandoned in the coal-bearing sediment package of mid package of the section. And the researchers have determined that these fossils belong to Cypridea copulenta Lubimova, Limnocypridea grammi Lubimova and Lycopterocypris infantilis Lubimova indicating they belong to the mid to late part of the Lower Cretaceous Barremian stage.

\section{DISCUSSION}

Sediment accumulation and Paleoenvironment: The Lower Cretaceous sediments of the section are lithologically composed of mainly clay, fine -grained siltstone and rarely conglomerate layers (Fig. 13).

The study area had been represented by continental, freshwater lacustrine basin during the most time of the Early Cretaceous, which was evidenced by number of fossils such as molluscs, ostracods, fish and turtles. And it could be considered that the plant cover that spread throughout the shores of the lake had been moved and accumulated forming coal seams during the sediment accumulation. The Fig. 14 shows the partial sections of sedimentology. The external morphology and color differences of the two types of conchs and snails, especially gastropod snails, which are the major findings of paleontology, are evidencing sometimes happened sharp temperature changes. The Hangaiemys leptis turtle is medium in size and is believed to point to a fresh, gentle and stable aquatic environment. Also, one of the criteria for a freshwater environment was evidenced by fish fossils.

\section{CONCLUSION}

The main result of the study was the findings and the age determination for many classes and groups of animals and plant fossils from the Ergel-Khaliv area. They had been existing, spreading there for quite a long geological time, during the Lower Cretaceous, Barriamian-Lower Aptian stages. This may indicate the need for further review of the summaries determining the Lower Cretaceous sediments of the site, into Aptian-Albian sediments of the Khukhteeg Formation. Also, the sediments contain fossils such as molluscs, fish, amphibians (turtle) and continental leaf plants, which are important for the paleo-ecosystem studies evidencing of their accumulation on lake shores. And this circumstance will be background for further studies. Many of the results are being the preliminary determination of the paleoenvironmental conditions during the sediment accumulation. One of the data from the research suggests that there is a possibility for further studies on paleosoil, here. In addition, the section is considered as an important object of comparative biostatigraphy of the Lower Cretaceous coal-bearing sediments in Mongolia. The Ergel-Khaliv (or Dun-ovoo) section may be the subject of further research, possibly affecting the boundaries of the Lower and Upper periods of the Cretaceous.

\section{ACKNOWLEDGMENTS}

This study was supported by Wolf Resource Co. Ltd. We thank for the Dr. Kh.Tsogtbaatar, Director of the Institute of Paleontology, Mongolian Academy of Sciences; and also colleagues of Wolf Resource Co. Ltd., and especial thanks to researcher B.Belgutei, of the Institute of Paleontology.

\section{REFERENCES}

Barsbold, R. 1972. Campelominae. Biostratigraphy and freshwater molluscks of the Upper Cretaceous sediments, Gobi, Mongolia, Academy of Sciences USSR, p. 7173. (in Russian)

Bayartsengel, Ts., Janchiv, B., Javkhlanbold, D., Dorjsuren, Sh., Uuganbayar, D., Munkhtulga, O., Erdenebold, D., Saranchimeg, S. 2015. Report about Geological Mapping and Basic Prospecting works at scale 1:50000 conducted to Khatanbulag and Ulaanbadrakh soums, Dornogobi province, No.8175, p. 72-77. (in Mongolian)

Berkey, C., Morris, E.K. 1927. Geology of 
Mongolia, American Museum of Natural History, New York, v. 2, p. 3-475.

Bunburuu, G., Ulziibayar, J., Agvaansambuu, E. 1999. Report about Geological Prospecting and Mapping works at scale 1:50000 conducted territory of Dornogobi province by Khar-Tolgoi Geological Team. No.5281, p. 94-103. (in Mongolian)

Burenkhuu, E., Gotovsuren, A., Badarch, G., Dagvatseren, A. 1995. Report about Complex geological survey at scale 1:200000 conducted to Galba Gobi, No.4877, p. 94-103. (in Mongolian)

Durante, M.V., Dobruskina, I.A., Makulbekov, N.M., Sodov, J., Luvsantseden, U. 2009. World of land plants-Embryophyta (Cormophyta). Phanerozoic Flora, p. 59-120. (in Russian)

Goldenberg, V.I., Sanjaadorj, D., Baasandorj, T., Baatar, N., Vertlub, V.I., Dobrov, G.M., Zabotkin, L.V., Lopatin, V.I., Lopatina Ya.V., Mosiondz, K.A., Nurakhov, V.I., Usna-Ekh, G., Tsedenbal, Ch. 1978. Report on results of geological mapping and prospecting works at scale 1:200000, conducted to regions of Umnugobi, Dundgobi and Dornogobi provinces, No.2724, p. 327-350. (in Russian)

Krassilov, V.A. 1982. Early Cretaceous flora of Mongolia. Palaeontographica, Abteilung B, Band, v. 181, p.1-43.

Lebedev, Ye.L. 1974. Albian Flora and Cretaceous Stratigraphy of Western Priokhotya, Edition No.254, p. 41-59. (in Russian)

Makhbadar, Ts. 2012. The Cretaceous System, Mesozoic. in Byamba, J. ed., Geology and Mineral Resources of Mongolia, Stratigraphy v. I, p. 471-509. (in Mongolia)

Marinov, N.A., Hasin, R.A. 1973. Lower Division of Cretaceous System. Geology of the People's Republic of Mongolia, Stratigraphy, v. I, p. 444-463. (in Russian)
Martinson, G.G. 1961. The Mesozoic and Cenozoic Molluscs from Continental sediments of Siberian Platform, Transbaikalia and Mongolia. Academy of Sciences, USSR, 359 p. (in Russian)

Martinson, G.G., Shuvalov, V.F. 1973. The Stratigraphic division of Upper Jurassic and Lower Cretaceous of the Southeastern Mongolia. Academy of Sciences, USSR, Series of Geology, p. 27-41. (in Russian)

Osborn, H.F. 1924. Psittacosaurus and Protigaunodon: Two Lower Cretaceous Igaunodons from Mongolia. American Museum Novitates, v. 127, p. 16.

Rozhdestvensky, A.K. 1955. New Data about Psitakkosaurs, the Cretaceous Ornithopods. Issues related to Geology of Asia, v. 2, Academy of Sciences, USSR. (in Russian)

Sukhanov, V.B., Narmandakh, P. 2006. New taxa of Mesozoic turtles from Mongolia. Fossil Turtle Research v. 1, p. 119-127. (in Russian)

Svichenskaya, A.A. 1954. Crustaceans and anamniotes of Lower Mesozoic continental sediments of Mongolia - (Lycoptera fragilis from Lower Cretaceous of Mongolia), p. 195198. (in Russian)

Sychevskaya, Ye.K. 2004. Basic stages of the development of freshwater ichthyofauna of Mongolia in the Mesozoic. Problems of paleontology of Central Asia. SRMPE. p. 5860. (in Russian)

Turishchev, I.Ye. 1955. To the issues about Cretaceous Sedimentation of Southeastern part of Mongolia. Publication of VNIGRI, v. 94, p. 99-107. (in Russian)

Vakhrameyev, V.A. 1990. Jurassic and Cretaceous floras of Mongolia and the climate of that time. Paleofloristics, phytogeography and Mesozoic climate, Selected abstracts, p. 188-193. (in Russian) 
Appendix 1.
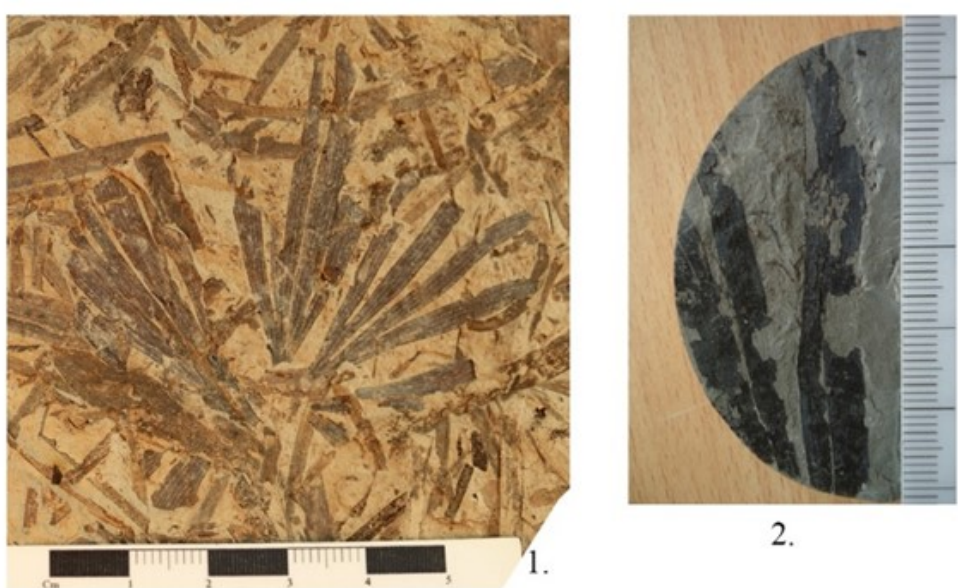

2.
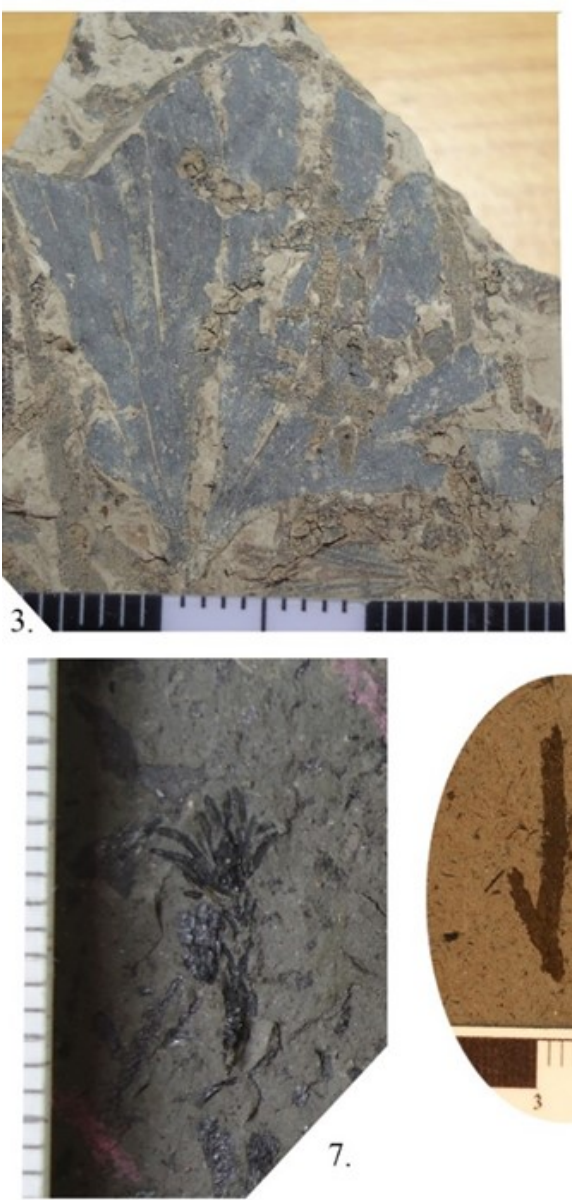

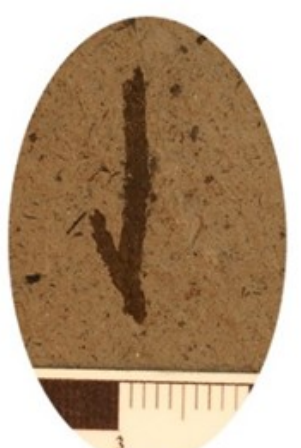

8.

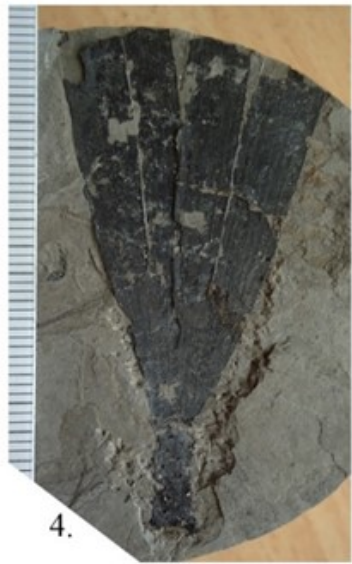

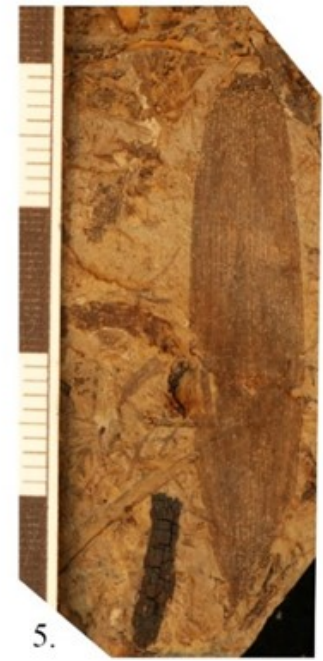
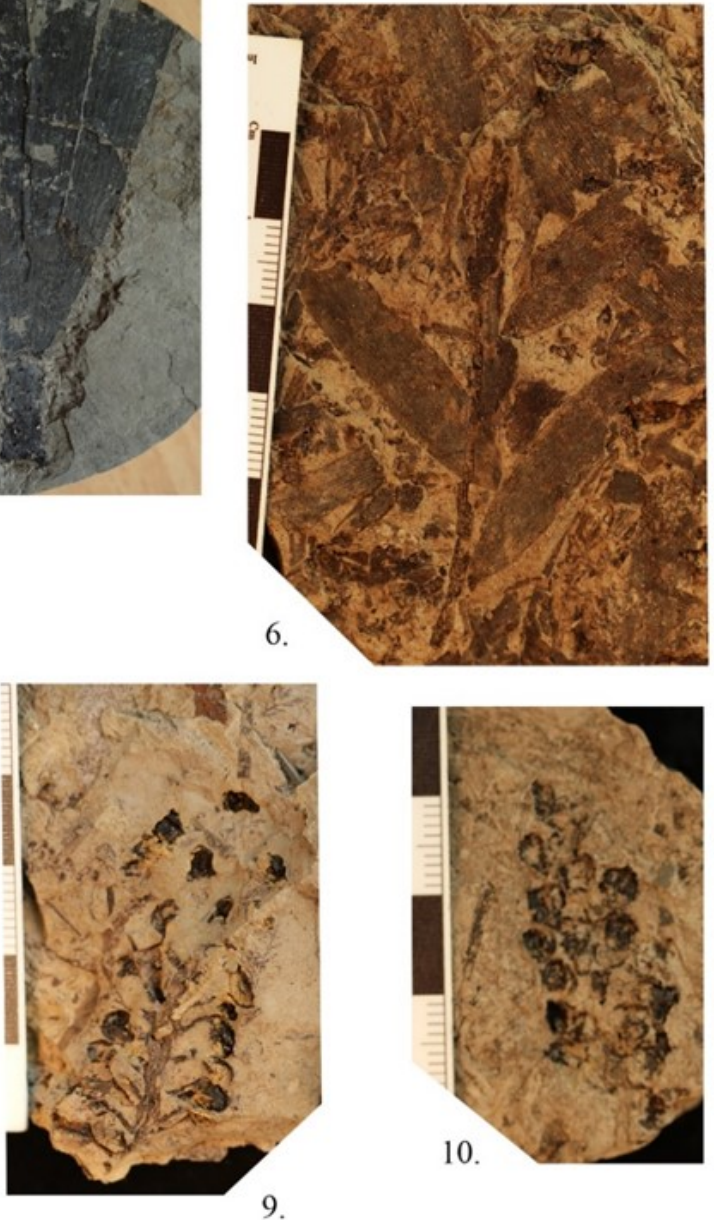

Plate I. Figs 1-10: 1-Acrostichopteris cf. vachrameevii E. Lebedev, Lower Cretaceous, Lower Albian; 2 Sphenobaiera cf. longifolia (Pomel) Florin, Lower Cretaceous, Barriaman-Aptian; 3 and 4: Sphenobaiera sp.; 5-Podozamites sp.; 6-Podozamites cf. eichwaldii (?) Heer, Middle Jurassic-Lower Cretaceous, Barriaman; 7-Swedenborgia sp., Lower Cretaceous; 8-Brachyphyllum sp., Lower Cretaceous; 9 and 10: Ixostrobus sp., Middle Jurassic-Lower Cretaceous. 


\section{Appendix 2.}
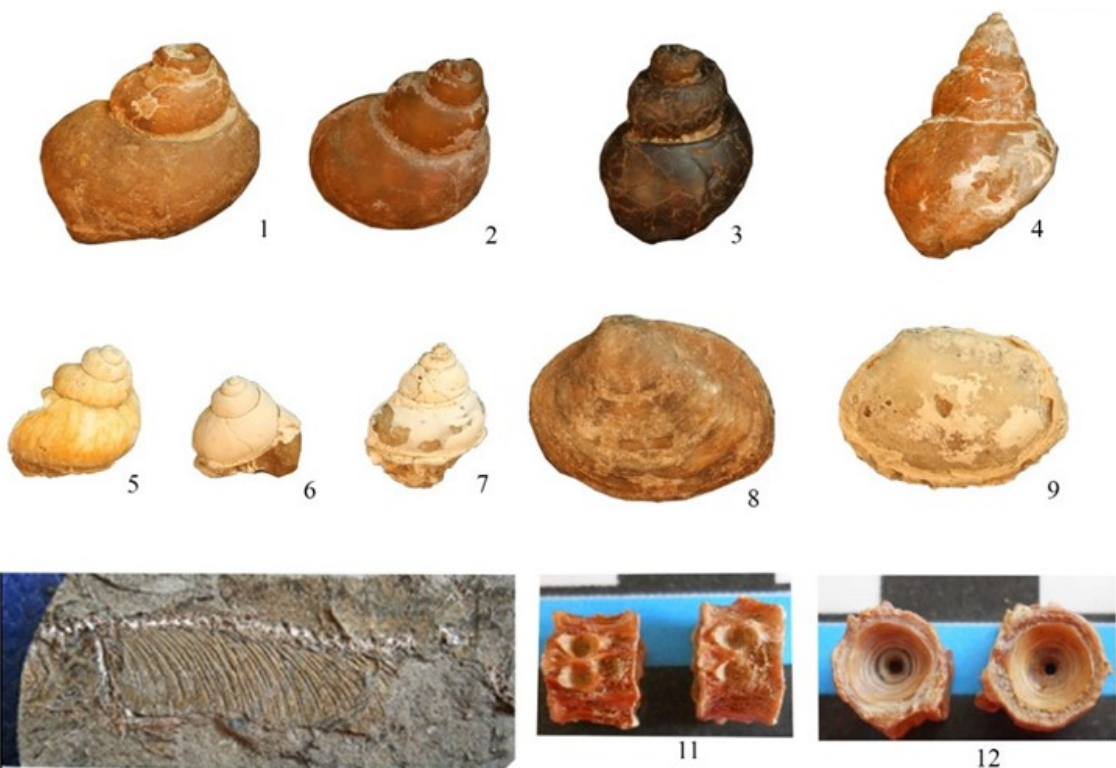

10
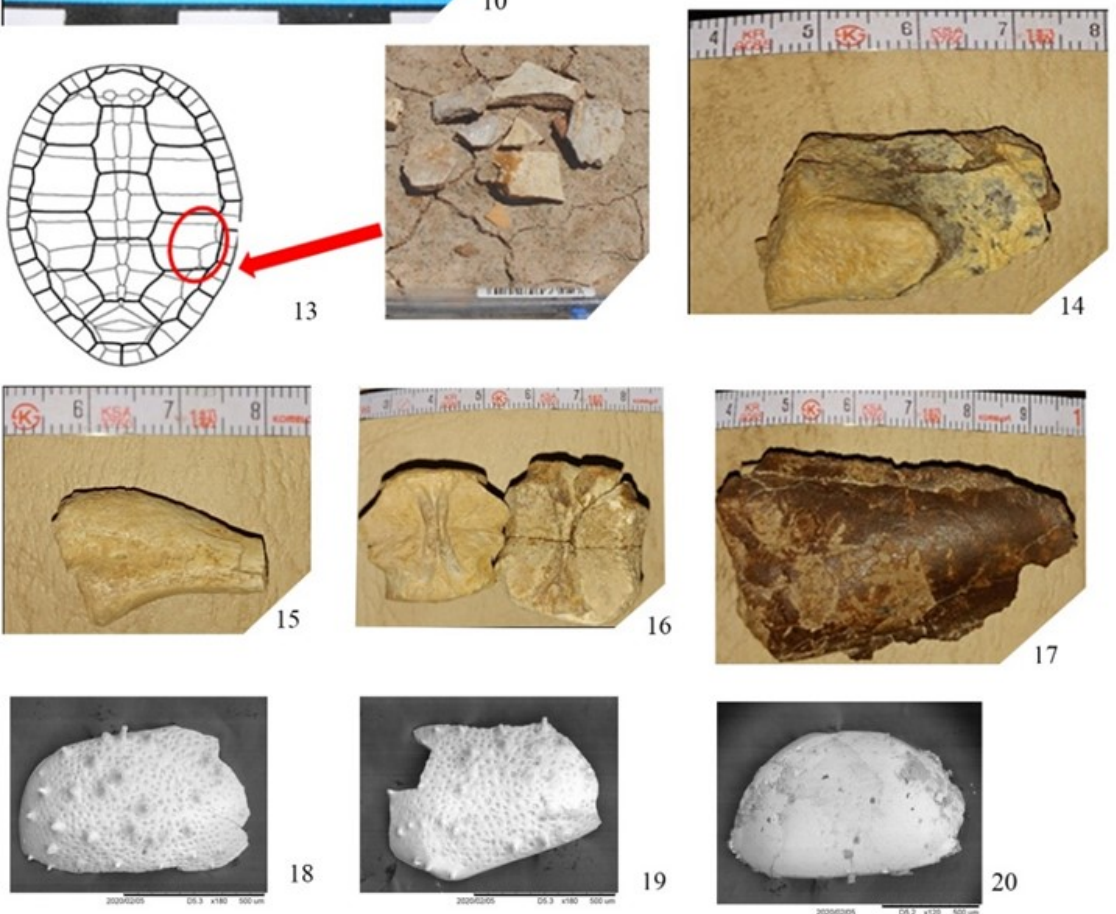

Plate II. Figs. 1-20. 1-3: Viviparus robustus Martinson, Lower Cretaceous, Barremian; 4-Campeloma yihsiensis Grabau, Lower Cretaceous, Barremian; 5 and 6: C. mongolica Martinson, Lower Cretaceous, Barremian-Aptan; 7: Lioplax sp.; 8 and 9: Unio pygmaeiformis Martinson, Lower Cretaceous, Barremian; 10Lycoptera sp., Lower Creatceous; 11 and 12: Peipiaosteus sp., Lower Cretaceous; 13: Hangaiemys leptis Sukhanov emend Narmandakh, Lower Cretaceous; 14, 17: Dinosaur bone fossil-15 and 16: Psittacosaurus sp., Lower Cretaceous, AptianAlbian (?); 18-20- Ostracods: 18-Cypridea copulenta Lubimova; 19Limnocypridea grammi, Lubimova; and 20- Lycopterocypris infantilis Lubimova, Lower Cretaceous, Barremian. 